\title{
高职院校工程类毕业生就业存在的问题和对策
}

梅燕飞

云南经济管理学院

DOI:10.18686/bd.v1i9.810

[摘 要] 结合工程类的造价专业, 对其毕业生就业存在的问题和对策进行了探讨分析。高职院校工程造价专业以培养具 有较好职业道德素养和持续学习能力, 并能运用工程造价管理专业知识结合信息化手段去解决工程造价计算与控制等实 际问题的人才为培养目标。但目前我国工程造价专业毕业生的就业现状诸多问题, 因此必须加强对其进行分析。

[关键词] 高职院校;工程造价毕业生; 就业;问题;对策

1 高职院校工程造价专业毕业生就业存在的主要问题

结合笔者调查分析, 认为高职院校工程造价专业毕业 生就业存在的问题主要表现为: (1)毕业生再就业上缺乏主 动意识。调查分析, 很多造价专业学生毕业后并没有从事与 造价专业关系最密切的造价员、招投标专员等工作, 而是选 择了施工员、监理员等与建筑工程管理专业、施工技术专业 紧密关联的工作。追其原因, 并不是他们不想从事工作环境 相对优越、待遇相对较高的造价岗位, 主要还是毕业生认为 自身能力不够,无法适应造价岗位技能要求。经过求职“挫 折“后, 自信心受到打击, 过分依赖老师、家人、校友等推荐 介绍, 缺乏主动求职意识。(2)就业面狭窄。目前很多高职院 校侧重于培养 “土建工程造价员”, 而对安装、道路桥梁、水 利水电、园林造价员等未有涉及, 导致大部分学生仅仅对土 建工程造价部分熟悉。而目前的建筑市场对于 “土建工程造 价员”需要更多的 “一专多能” 人才, 这对仅会土建工程造价 的学生而言, 使其就业面相对狭窄。(3)就业期望值过高导 致部分学生长期 “待业”。工程造价专业作为近年来多手可 热的专业, 很多工程造价专业毕业生不能准确地认识当前 就业形势, 择业期望值过高, 把丰厚待遇、舒适的工作条件、 在职公司为大型公司等作为择业标准, 不愿从事条件艰苦 的工作, 不愿到经济比较落后的地区工作。也有些学生对施 工员、监理员、资料员这些工作不屑, 处于 “长期待业” 状态。

\section{2 高职院校工程造价专业毕业生就业问题的对策}

2.1 培养学生正确的就业心态。随着城市化建设的逐步 完成, 建筑工程项目将会逐步减少, 相对于建筑类人才的 “施工员” “技术员” “一线工人”等, 工程造价员的需求会更 少。因此, 首先要让学生认识到目前建筑市场的就业形势, 将自己正确定位; 其次要让学生明确自己的能力水平和用 人单位需求之间的差距, 端正就业心态, 摆正自己的位置, 避免眼高手低。最后要让学生明白正确的定位加上自身不 解努力, 他可以成为 “采手可热的人才”, 从而促使学生提高 自信,拥有健康、平和的就业心态。

2.2 课程设置上以市场需求为导向, 加大实践教学和顶 岗实习的力度。学校在制定人才培养方案及课程设置上应 以培养学生实践操作能力为目标, 结合造价工作现状, 不断
优化课程设置。结合本专业特点, 根据市场的需求状况, 整 合课程结构, 加大实践教学和顶岗实习的力度。实践教学不 仅仅是指工程造价计算实训方面，还应扩宽至包括制图与 识图的基本知识、施工程序、施工工艺、施工技术、工程造价 软件的运用、工程量清单的编制、招标控制价的编制、招投 标文件的编制等。顶岗实习是指学生在学完所有理论知识 后, 通过到企业实习, 理论联系实际, 以提高学生适应社会 的能力和综合运用专业技术的能力, 为学生毕业后走人踏 人工作岗位积累经验,奠定基石。

2.3 提高自身综合素质并加强道德修养, 诚实守信, 树 立高尚的职业道德。市场经济的逐渐完善, 仅靠单一的专业 知识已不能满足企业所需。所以学生要秉承“先做人, 后做 事”的理念, 加强自身综合素质的培养,包括全面提高自身 的知识结构、交际能力、心理素质、表达能力、学习能力、气 质修养等。因此高职院校在对学生进行就业指导时要从以 下几方面人手:一要学会做人, 要做诚实守信的人, 以脚踏 实地的作风择业就业, 慎重迈好就业第一步, 为将来打下良 好的基础, 提高自己的沟通能力, 拓展自己的人脉圈; 二要 学会做事, 努力学习专业知识, 掌握实践技能, 积极参加社 会实践, 不断提升社会适应能力和综合素质。三要学会学 习, 掌握学习的方法, 持续学习以适应未来 “学习型社会” 发 展的需要。对于企业来说, 具备良好的职业道德一直是人才 选用的首要条件。调查显示, 多数工程造价用人单位把毕业 生的道德修养放在了首位, 具有敬业精神、团队合作精神、 吃苦精神、诚信品质的大学毕业生尤为受欢迎。所以毕业生 提高综合素质同时, 更应该注重职业素养,树立正确的人生 观、价值观，切实提高自身的道德修养和诚信品质。

\section{3 结束语}

随着城市化建设的不断推进，使得工程项目建设日益 增多, 项目工程建设投资规模的不断扩大, 使得工程造价专 业近几年成为了热门专业, 同时也给就业带来诸多问题, 因 此需要对其存在的问题,采取相应的对策。

\section{参考文献:}

[1]曹莤.工程造价专业人才培养模式浅析[J].绥化学 院学报,2014(09) 